\title{
Protective Effects of Punicalagin on Caco-2 Intestine Cell Line under Oxidative Stress Caused by Tert-butyl hydroperoxide
}

\author{
Ulfat Omar ${ }^{\mathrm{a}, \mathrm{b},{ }^{*},}$, Akram Aloqbi ${ }^{\mathrm{a}, \mathrm{c}}$, Marwa Yousr $^{\mathrm{a}}$ and Nazlin Howell ${ }^{\mathrm{a}}$ \\ ${ }^{a}$ University of Surrey, Faculty of Health and Medical Sciences, Division of Nutrition and Metabolism, \\ Guildford, Surrey, GU2 7XH, UK \\ ${ }^{b}$ King Abdulaziz University, Faculty of Science, Biochemistry Department, Jeddah, PO Box 40288, zip code \\ 21499, Saudi Arabia \\ ${ }^{c}$ Present Address University of Jeddah, Faculty of Sciences and Arts - Alkamel, Biology Department, Jeddah, \\ PO Box 80327, Jeddah 21589, Saudi Arabia
}

\begin{abstract}
Hydrolysable tannin polyphenols from pomegranate (punicalagin) have been reported to show a wide range of health properties correlated to their high antioxidant and free radical scavenging activities. The objective of the current study was to investigate the protective effect of punicalagin on cell viability and redox status of cultured Caco-2 cells exposed to oxidative stress induced by tert-butyl hydroperoxide. The production of malondialdehyde, and total glutathione levels, as well as the generation of reactive oxygen species were used as markers of cellular oxidative status. Pretreatment of Caco-2 cells with 5 and $10 \mu \mathrm{M}$ punicalagin for 24 hours significantly protected cell viability after exposure to tert-butyl hydroperoxide $\mathrm{IC}_{50}=3 \mathrm{mM}$ for 2 hours. The examined doses prevented the decrease of total glutathione and the increase of malondialdehyde induced by tert-butyl hydroperoxide in Caco-2 cells. Reactive oxygen species generation provoked by tert-butyl hydroperoxide was significantly reduced at the same concnetrations. Finally, cell morphology with treatments before and after induction by tert-butyl hydroperoxide showed irreversible effect of the oxidizing agent. The results of the biomarkers analyzed showed that treatment of Caco-2 cells with the natural dietary antioxidant punicalagin protected the cells against oxidative stress.
\end{abstract}

Keywords: Polyphenols, Malondialdehyde, Glutathione, Reactive oxygen species, morphology.

\section{INTRODUCTION}

Oxidative damage to cellular components occurs if there is an imbalance between the antioxidant capacity of cellular antioxidants in a biological system and the quantity/activity of reactive oxygen species (ROS). Excessive ROS production leads to tissue injury and it is the basis of several human diseases such as coronary heart disease and cancer [1]. Free radicals can alter the poly-unsaturated fatty acids present in the cell membrane and change the permeability of the membrane itself. The lipid bilayer exists in all cellular organisms and forms the plasma membrane, and the surrounding membrane of organelles such as the endoplasmic reticulum and mitochondria. In addition to causing direct cellular damage to the membrane, the lipid peroxidation products, such as malondialdehyde (MDA), are also very toxic [2]. For this reason, biological systems are normally protected from oxidation by their antioxidant defence systems and by antioxidant. One of the important antioxidant defence mechanisms at cellular level is the concentration of reduced glutathione (GSH).

*Address correspondence to this author at the King Abdulaziz University, Faculty of Science, Biochemistry Department, Jeddah, PO Box 40288, zip code 21499, Saudi Arabia; Tel: +966503675685; E-mail: uomer@kau.edu.sa

ISSN: 2223-3806 / E-ISSN: 1927-5951/15
Glutathione is a tri-peptide of glutamic acid, cysteine and glycine; it has the ability to work as an antioxidant, protecting the cell from damage caused by ROS [3]. Reduced and oxidized forms of GSH are both present in the cell at the same time. In healthy cells and tissues, the reduced form of GSH accounts for more than $90 \%$, while the oxidized form (GSSG) accounts for less than $10 \%$. A severe decrease in GSH level in the cell leads to the susceptibility of the cell to oxidative damage by radicals [3]. Increased level of intracellular ROS leads to depletion of glutathione [3]. Previous studies have indicated a relationship between polyphenols and GSH levels in the cell. Polyphenols have the ability to prevent the decrease of GSH levels induced by tert-butyl hydroperoxide (t-BOOH) [3, 4, 5]. Thus, natural products containing polyphenols have been proposed as antioxidants.

Epidemiological studies have shown that the intake of polyphenols may reduce the risk of some diseases such as cancer and cardiovascular disease $[6,7]$. Pomegranate juice has a high content of phenolic compounds (such as punicalagin isomers, ellagic acid) and anthocyanins (such as delphinidin, cyanidin, and pelargonidin) [8]. Gallic and ellagic acid link to glucose molecules to form punicalagin. The high antioxidant properties of pomegranate juice are due to the presence of punicalagin [8]. Punicalagin is a yellow

(c) 2015 Lifescience Global 
water-soluble compound that is mainly present in the pomegranate husk and is extracted in the juice during fruit processing [8].

Previous studies on polyphenols and flavonoids demonstrated their ability to prevent lipid peroxidation in living cells by trapping free radicals [9, 10, 11]. The tissue with the highest exposure to dietary flavonoids and polyphenols is the intestine. For this reason, human intestinal Caco-2 cells were used as a model to investigate the protective effects of punicalagin under oxidative conditions caused by $\mathrm{t}-\mathrm{BOOH}$, by measuring GSH, ROS and MDA levels.

The objective of the present study was to investigate the potential protective effect of different punicalagin concentrations against oxidative stress induced by $\mathrm{t}-\mathrm{BOOH}$ in Caco-2 cells. Cell viability and several markers of oxidative damage were used to examine the effect of punicalagin on cell viability and their effect on the antioxidant system of Caco-2 cells stressed by $3 \mathrm{mM}$ of $\mathrm{t}-\mathrm{BOOH}$. Levels of malondialdehyde (MDA) as a marker of lipid peroxidation; scavenging of reactive oxygen species (ROS); concentration of total glutathione (GSH) and cell morphology were parameters that were determined in the present study.

\section{MATERIALS AND METHODS}

\subsection{Materials}

The Caco-2 cell line was obtained from the European Collection of Cell Cultures (ECACC) Salisbury, UK. Phosphate buffered saline (PBS) tablets were obtained from Oxoid, Hampshire, UK. Punicalagin, t-BOOH to stress Caco-2 cells, 3-(4,5Dimethylthiazol-2-yl)-2,5-diphenyltetrazolium bromide (MTT dye) to measure cell viability, thiobarbituric acid (TBA), trichloroacetic acid (TCA), 1,1,3,3tetraethoxypropane (TEP), DMSO, and cell lysis buffer were obtained from Sigma-Aldrich Chemical Co, Poole, UK. Foetal bovine serum (FBS), trypsin-EDTA solution, L-glutamine $(200 \mathrm{mM})$, non-essential amino acids (NEAAs), Dulbecco's Modified Essential Medium

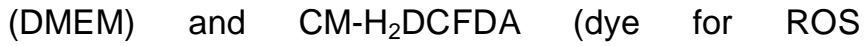
measurmment) were purchased from Invitrogen, Paisley, UK. A total glutathione peroxidase kit was obtained from the Cell Biolabs, INC, Cambridge, UK.

\subsection{Methods}

\subsubsection{Cell Culture}

Caco-2 cells were grown in DMEM supplemented with $20 \%$ FBS, 1\% glutamate, 1\% NEAA and $1 \%$ penicillin. Cells were sub-cultured when reach $70 \%$ -
$90 \%$ confluent in a humidified atmosphere in $5 \% \mathrm{CO}_{2}$ at $37^{\circ} \mathrm{C}$.

\subsubsection{Determination the Cytotoxicity of Punicalagin by MTT Assay}

The MTT assay is dependent on the conversion of the soluble, yellow MTT dye to the insoluble purple formazan by the mitochondrial enzyme, succinate dehydrogenase. Succinate dehydrogenase cleaves the tetrazolium ring in the MTT structure and converts it to formazan $[12,13]$. Different concentrations of $\mathrm{t}-\mathrm{BOOH}$ $1,3,5$ and $10 \mathrm{mM}$ were assessed to determine the $\mathrm{IC}_{50}$. The cytotoxic effect of different concentrations of punicalagin ranging from $1-100 \mu \mathrm{M}$ on Caco-2 cells was studied. Caco-2 cells were seeded into 96-well tissue culture plates at $1 \times 10^{4}$ cells/200 $\mu \mathrm{l}$ DMEM complete media. After 24 hours, punicalagin was added to each well to give a final concentration of 1,3 , $5,10,50$, and $100 \mu \mathrm{M}$. The non-toxic dose 1, 3, 5, and $10 \mu \mathrm{M}$ followed by 2 hours incubation with $3 \mathrm{mM}$ $t-\mathrm{BOOH}$ after determination the $\mathrm{IC}_{50}$ [14]. The MTT assay was performed by adding $20 \mu \mathrm{l}$ MTT dye $(5 \mathrm{mg} / \mathrm{ml})$ to each treated well. The plate was incubated for 2 hours at $37^{\circ} \mathrm{C}$. At the end of incubation time, the culture media was aspirated and $50 \mu \mathrm{l}$ of DMSO was added to each well. The formazan crystals produced were dissolved completely by shaking the plate for 30 seconds at room temperature. The colour was measured at $492 \mathrm{~nm}$ using a plate reader (Boehring CO, Marburg, Germany).

\subsubsection{Determination of Thiobarbituric Acid Reactive Substances (TBARS)}

TBARS are considered as a marker of lipid peroxidation [2,15]. The spectrophotometric method of Ohkawa et al., (1979) was used with some modifications to detect TBARS in the biological system. The oxidation of poly-unsaturated fatty acid present in cell membranes produces MDA. Briefly, the treated cells were scraped with $3 \mathrm{ml}$ of $20 \%$ TCA. Followed by adding $2 \mathrm{ml}$ of $0.7 \%$ TBA and heated at $100{ }^{\circ} \mathrm{C}$ for 1 hour. After cooling, the tubes were centrifuged at 1500 $\times g$ for 10 minutes. The intensity of the pink colour was determined by reading the absorbance at $535 \mathrm{~nm}$ using a spectrophotometer (UNICAM Spectronic, Leeds, UK). The MDA concentration was expressed in $\mathrm{nmol}$ of $\mathrm{MDA} / \mathrm{mg}$ protein. Trolox at a concentration of $0.01 \%$, was used as positive control.

\subsubsection{Measurement of Cellular Reactive Oxygen Species (ROS)}

Dichlorofluorescein dye (non-fluorescent CM$\mathrm{H}_{2}$ DCFDA) has the ability to diffuse through cell 
membranes. In the cytoplasm, this dye is hydrolysed enzymatically by intracellular esterases and rapidly converted to fluorescein dye (DCF) in the presence of ROS. The fluorescence intensity of DCF is proportional to the ROS content [17]. Caco-2 cells were seeded in $25 \mathrm{~cm}^{2}$ flasks at a density of $1 \times 10^{6}$ cells $/ \mathrm{ml}$. The treatments were applied for 24 hours after the cells reached $60-70 \%$ confluence. Following incubation, the cell incubated with $\mathrm{t}-\mathrm{BOOH} 3 \mathrm{mM}$ for 2 hours. At the end of the incubation time, the cells were trypsinised and the cell suspension centrifuged for 3 minutes at $150 \times g$ using a Beckman GRP centrifuge. The supernatant was discarded and the cells were resuspend in $1 \mathrm{ml}$ PBS and incubated with $5 \mu \mathrm{M}$ of CM$\mathrm{H}_{2}$ DCFDA (prepared in DMSO) for 30 minutes at $37^{\circ} \mathrm{C}$ and $5 \% \mathrm{CO}_{2}$. At the end of the incubation time, the cells were kept on ice under low light conditions and the DCF florescence was measured using a BD FACSCanto flow cytometer (California, USA).

\subsubsection{Preparation of Cell Lysates}

The pre-treated Caco-2 cell with different punicalagin concentration and $\mathrm{t}-\mathrm{BOOH}$ were trypsinised and the cell suspensions centrifuged at $1500 \times g$ for 3 minutes. Supernatants were removed and the cell pellets were lysed by adding $300 \mu \mathrm{l}$ of lysis buffer (Sigma-Aldrich Chemical Co, Poole, UK). The sample was then immersed in ice for 20 minutes and stored at $-80{ }^{\circ} \mathrm{C}$ until used. Trolox $(0.01 \%)$ was used as a positive control

\subsubsection{Determination of Total Glutathione (GSH)}

A total GSH assay kit from Cell Biolabs was used to measure the total concentration of GSH by following the manufacturer's instructions.

\subsubsection{Morphology}

Cell morphology was assessed through microscopic observation of the Caco-2 cell line (treated with control, trolox, 5 and $10 \mu \mathrm{M}$ punicalagin) with and without incubation with $3 \mathrm{mM} \mathrm{t}-\mathrm{BOOH}$ for 2 hours. A photograph of the cells was taken using a Nikon Eclipse microscope at $10 \times$ magnification.

\subsection{Statistical Analyses}

All experiments were performed at least three times. For the 96-well micro-titer tissue culture plates, 4 replicate wells were used per category. The data were analyzed using Graphpad Prism software version 6. Significant differences between control and experimental values were determined by one way analysis of variance followed by the Bonferroni test using a significance level of $\leq 0.05$.

\section{RESULTS}

\subsection{Cytotoxicity of Punicalagin on Caco-2 by MTT Assay}

The cytotoxicity of punicalagin at different concentrations $(1-100 \mu \mathrm{M})$ is displayed in Figure 1. The average cell survival at concentrations between 1-10 $\mu \mathrm{M}$ was more than $95 \%$. There was no significant difference between the viability of control Caco-2 cells and those incubated with punicalagin at 1, 3, 5 and 10 $\mu \mathrm{M}$. However, there was a significant decrease with higher punicalagin concentrations compared to the control $(P<0.0001)$. The non- toxic dose was assessed to examine the protective effect of those doses under oxidative stress generated by $\mathrm{t}-\mathrm{BOOH}$.

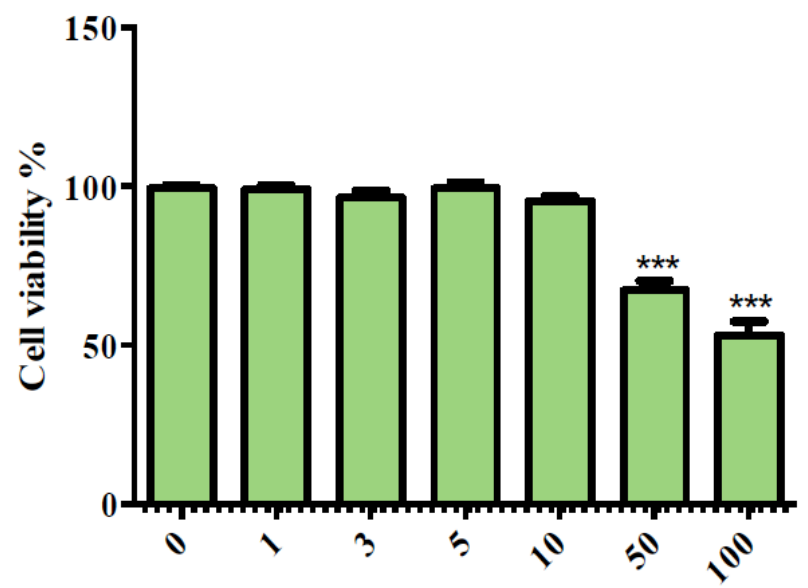

Punicalagin concentration. $\mu \mathrm{M}$

Figure 1: Cell viability of Caco-2 cells treated with different concentrations of punicalagin $(0-100 \mu \mathrm{M})$ for 24 hours. These data represent the mean \pm SD of at least 3 independent experiments. Comparisons of means were made using a oneway ANOVA followed by Bonferroni's test $\left({ }^{* * *}=\mathrm{P}<0.0001\right)$.

\subsection{The $\mathrm{IC}_{50}$ of $\mathrm{t}-\mathrm{BOOH}$}

Different doses of t-BOOH (1, 3, 5 and $10 \mathrm{mM})$ were incubated with Caco-2 cells for 2 hours to determine the $\mathrm{IC}_{50}$ of $\mathrm{t}-\mathrm{BOOH}$. The dose response curve in Figure 2 showed that the $\mathrm{IC}_{50}$ of $\mathrm{t}-\mathrm{BOOH}$, when applied to Caco-2 cells, was $3 \mathrm{mM}$. Consequently, this concentration was used to induce oxidative stress in Caco-2 cells and to measure the protective effect of punicalagin.

\subsection{Protective Effect of Punicalagin Against the Cytotoxicity of t-BOOH}

The protective effect of punicalagin $(1,3,5$ and 10 $\mu \mathrm{M})$ against the oxidative stress induced by $3 \mathrm{mM}$ 


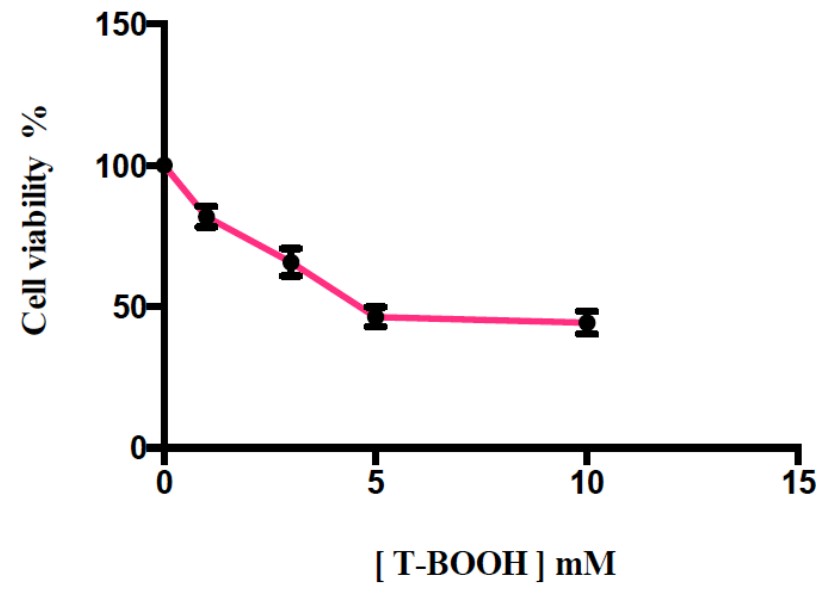

Figure 2: Dose-response curve for different concentrations of $\mathrm{t}-\mathrm{BOOH}(1,3,5$ and $10 \mathrm{mM})$ incubated for 2 hours with Caco2 cells. Values represent the mean $\pm S D, n=3$, the $I_{50}$ value was $3 \mathrm{mM}$ t-BOOH.

$\mathrm{t}-\mathrm{BOOH}$ is illustrated in Figure 3. No significant difference was seen between the cells incubated with 3 $\mathrm{mM} \mathrm{t}-\mathrm{BOOH}$ (58\% viability) and those pretreated with 1 $\mu \mathrm{M}(55 \%$ viability $)$ and $3 \mu \mathrm{M}(62 \%$ viability $)$ of punicalagin. However, there was a significant difference between the cells incubated with $3 \mathrm{mM}$ $\mathrm{t}-\mathrm{BOOH}$ and pretreated with 5 and $10 \mu \mathrm{M}$ punicalagin $(p<0.001$ and $p<0.0001$, respectively). Concentrations of punicalagin that have the ability to protect Caco-2 cells against $3 \mathrm{mM}$ t-BOOH were 5 and $10 \mu \mathrm{M}$; the cell viability with punicalagin was 64.4 and $71.5 \%$ respectively, versus $58 \%$ for $3 \mathrm{mM}$ t-BOOH only.

\subsection{Determination of MDA Concentration}

The effect of different concentrations of punicalagin on the production of secondary lipid oxidation product MDA was studied in Caco-2 cells. When trolox and different concentrations of punicalagin were incubated with Caco-2 cells without $\mathrm{t}-\mathrm{BOOH}$, non-significant differences in MDA concentration were observed in control cells compared with treated cells. Malondialdehyde concentrations were $37 \mathrm{nmol} / \mathrm{mg}$ for control, $35.5 \mathrm{nmol} / \mathrm{mg}$ for trolox, $35 \mathrm{nmol} / \mathrm{mg}$ for $5 \mu \mathrm{M}$ punicalagin and $34 \mathrm{nmol} / \mathrm{mg}$ for $10 \mu \mathrm{M}$ punicalagin respectively as presented in Figure 4.

There was a significant decrease in the production of MDA in cells pretreated with trolox, or 5 and $10 \mu \mathrm{M}$ punicalagin following induction of oxidative stress using $\mathrm{t}-\mathrm{BOOH}$ Figure 4. The most protective cell concentration against oxidative stress was $10 \mu \mathrm{M}$ punicalagin followed by trolox and then $5 \mu \mathrm{M}$ punicalagin compared with cells treated with $\mathrm{t}-\mathrm{BOOH}$ alone ( $p$ value $\leq 0.0001$ ). Concentrations of MDA were $27.7,38.7,41.4$, and $64.610 \mathrm{nmol} / \mathrm{mg}$ after treatment with $10 \mu \mathrm{M}$, trolox, $5 \mu \mathrm{M}$, or $3 \mathrm{mM} \mathrm{t}-\mathrm{BOOH}$ alone, respectively.

\subsection{Measurement of Cellular ROS Levels}

The ROS levels in Caco-2 cells exposed to t-BOOH in control and treated cells with trolox or punicalagin concentrations for 24 hours were measured using the $\mathrm{CM}-\mathrm{H}_{2}$ DCFDA dye.

Punicalagin (5 and $10 \mu \mathrm{M}$ ) reduced cellular ROS levels compared with control in 24 hours in pretreated Caco-2 cells exposed to $3 \mathrm{mM}$ t-BOOH for 2 hours Figure 5. ROS production was assessed by flow cytometric analysis using $\mathrm{CM}-\mathrm{H}_{2}$ DCFDA dye. Nonfluorescent $\mathrm{CM}-\mathrm{H}_{2} \mathrm{DCFDA}$ dye was converted to fluorescent DCF in the presence of ROS, as described in the method section previously. The pre-treated cell line with trolox and punicalagin showed a significant decrease in fluorescence intensity compared with t$\mathrm{BOOH}$ treated group $(\mathrm{p}<0.0001)$. This result indicates

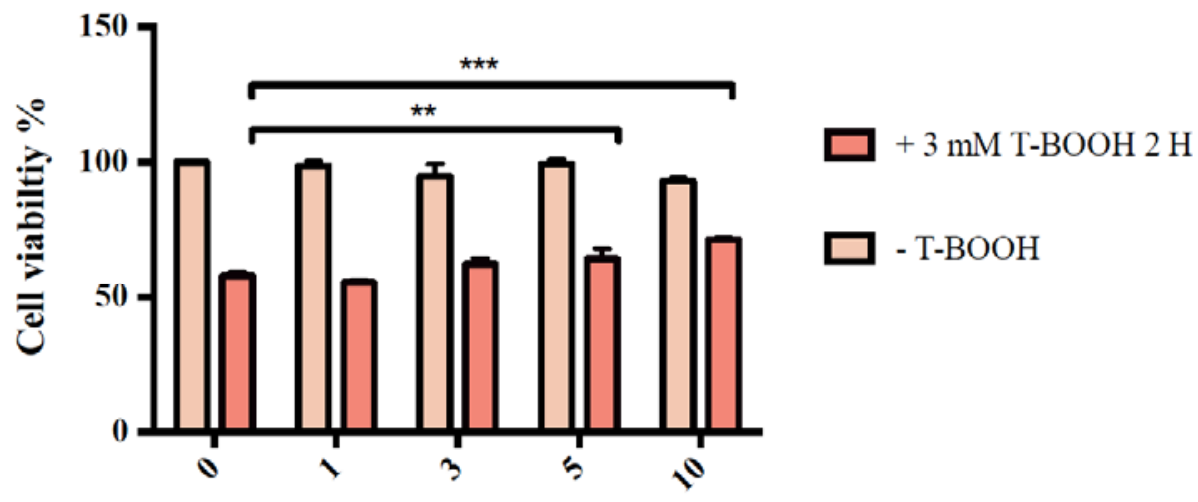

Punicalagin concentration. $\mu \mathrm{M}$

Figure 3: The viability of Caco-2 cells treated with different concentrations of punicalagin $(1,3,5$ and $10 \mu \mathrm{M})$ with and without $3 \mathrm{mM} \mathrm{t}-\mathrm{BOOH}$ after 2 hours. These data represent the mean $\pm \mathrm{SD}$ of at least 3 independent experiments. Comparisons of means were made using a one-way ANOVA followed by Bonferroni's test $\left(^{* *}=p<0.001\right.$ and $\left.{ }^{* * *}=p<0.0001\right)$. 


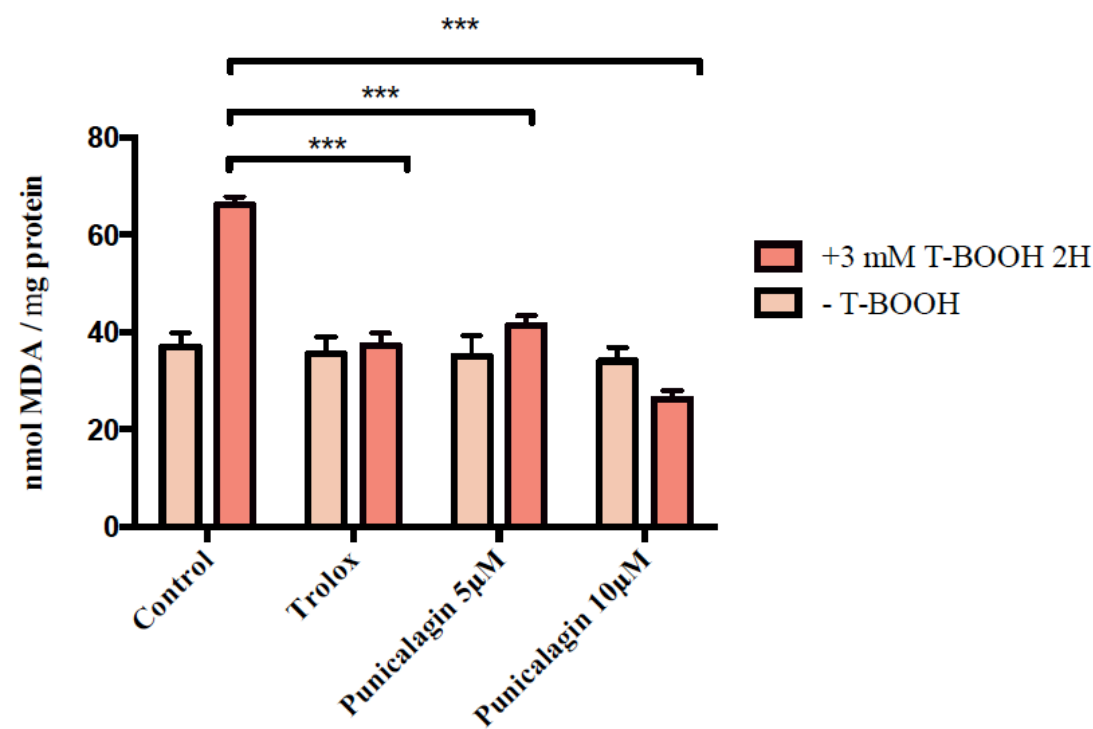

Figure 4: Concentration of MDA in Caco-2 cells treated with punicalagin and trolox individually with/without $3 \mathrm{mM} t-\mathrm{BOOH}$ for 2 hours. Values are the mean $\pm S D, n=3$. Comparisons of means were made using a one-way ANOVA followed by Bonferroni's test $\left({ }^{\star * \star} \mathrm{P}<0.0001\right)$. Trolox $0.1 \mathrm{mg} / \mathrm{ml}$ was used as antioxidant positive control.

that punicalagin has the ability to scavenge ROS and thereby protect cellular macromolecules such as lipids and proteins from ROS-mediated damage.

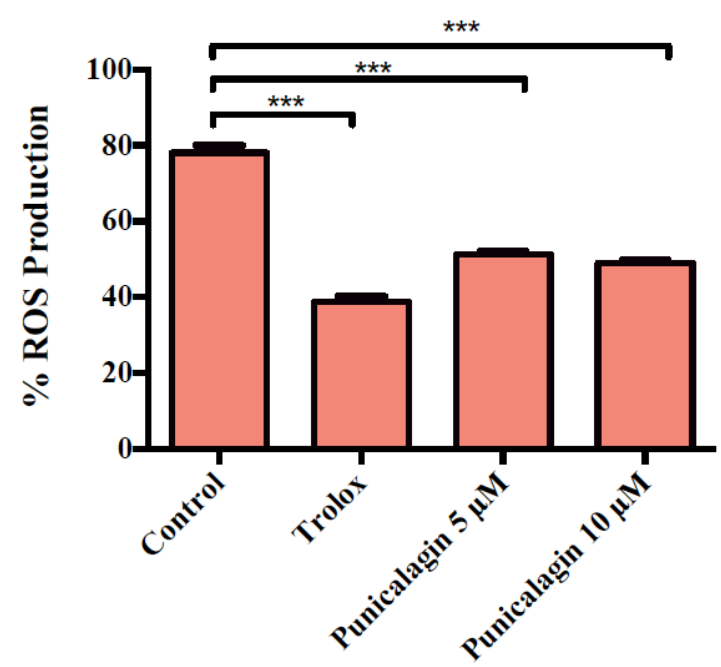

Figure 5: Cellular ROS levels in Caco-2 cells treated with punicalagin and trolox individually with $3 \mathrm{mM} \mathrm{t}-\mathrm{BOOH}$ for 2 hours. Values are the mean $\pm S D, n=3$. Comparisons of means were made using a one-way ANOVA followed by Bonferroni's test $\left({ }^{\star \star *} P<0.0001\right)$.

\subsection{Determination of Total Glutathione (GSH)}

In Figure 6, the total GSH level was significantly increased in the pre-treated cells with trolox, 5 and 10 $\mu \mathrm{M}$ punicalagin under $3 \mathrm{mM} \mathrm{t}-\mathrm{BOOH}$ oxidative induction compared with cells exposed to $3 \mathrm{mM} \mathrm{t}$ $\mathrm{BOOH}$ only. Levels of $\mathrm{GSH}$ were similar for all pretreated cells $(0.3 \mathrm{nmol} / \mathrm{mg})$. The $\mathrm{GSH}$ level of incubated cells with $\mathrm{t}-\mathrm{BOOH}$ was only $0.18 \mathrm{nmol} / \mathrm{mg}$. In the case of the trolox, 5 and $10 \mu \mathrm{M}$ punicalagin treated cells without $\mathrm{t}-\mathrm{BOOH}$ Figure $\mathbf{6}$; the level of $\mathrm{GSH}$ was significantly higher with trolox treatment $(p<0.0001)$ whereas no significant difference was observed with punicalagin treatment compared with the control.

\subsection{Morphological Changes to Caco-2 Cells Treated with Punicalagin}

The protective effect of different concentrations of punicalagin $(5 \mu \mathrm{M}$ and $10 \mu \mathrm{M})$ on Caco-2 cells subjected to $3 \mathrm{mM}$ t-BOOH oxidative stress was investigated by microscopy for 24 hours. Figure 7 shows the morphological changes observed in Caco-2 cell lines stressed with $\mathrm{t}-\mathrm{BOOH}$ compared with control cells. In contrast, cells pre-treated with different punicalagin concentrations and then stressed with t$\mathrm{BOOH}$ appeared healthy, with morphology appearing the same as the control (Caco-2 cells) as well as cells exposed to punicalagin only.

\section{DISCUSSION}

Pomegranate punicalagin, a hydrolysable tannin polyphenol compound protected Caco-2 cells against the $\mathrm{IC}_{50}(3 \mathrm{mM})$ of $\mathrm{t}-\mathrm{BOOH}$ at 5 and $10 \mu \mathrm{M}$. Different defence mechanisms in pretreated Caco-2 cells stressed with $3 \mathrm{mM}$ of $\mathrm{t}-\mathrm{BOOH}$ for 2 hours has been investigated. This protective effect of punicalagin was confirmed by microscopy, where adverse morphological cell changes were less apparent with antioxidant treatment. The cells looked healthy which demonstrates the protective effect of punicalagin against oxidative stress. 


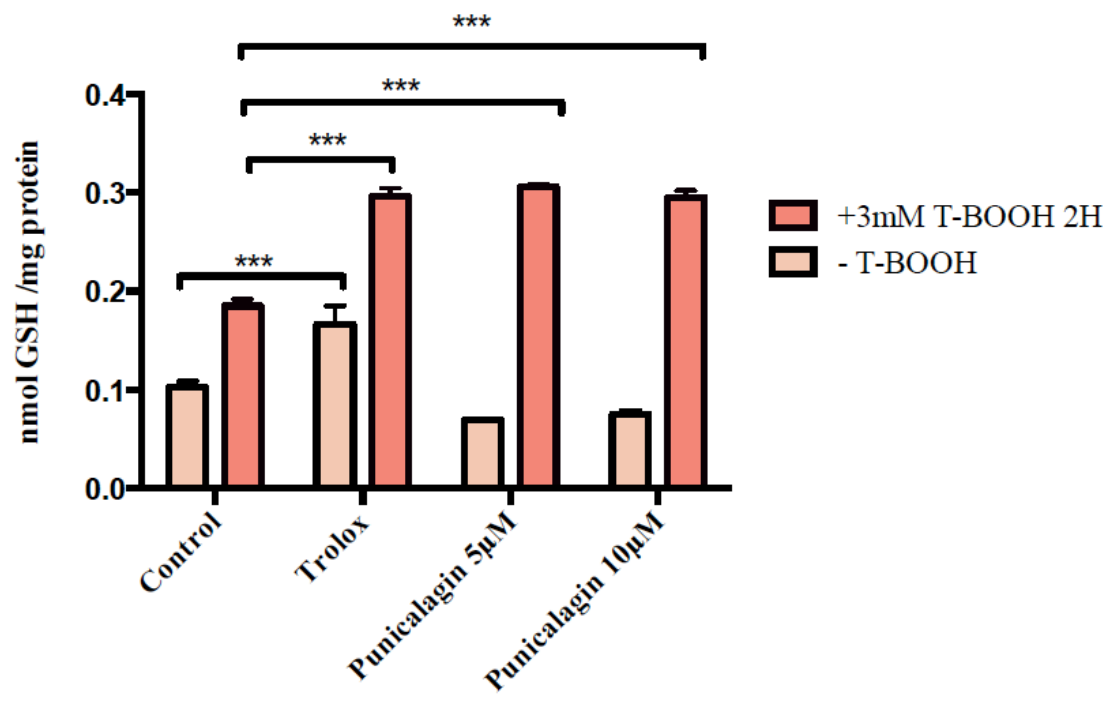

Figure 6: Glutathione (GSH) level in Caco-2 cells treated with punicalagin and trolox individually with/without $3 \mathrm{mM} \mathrm{t-BOOH}$ for 2 hours. Values are the mean $\pm S D, n=3$. Comparisons of means were made using a one-way ANOVA followed by Bonferroni's test $\left({ }^{* * *} P<0.0001\right)$.

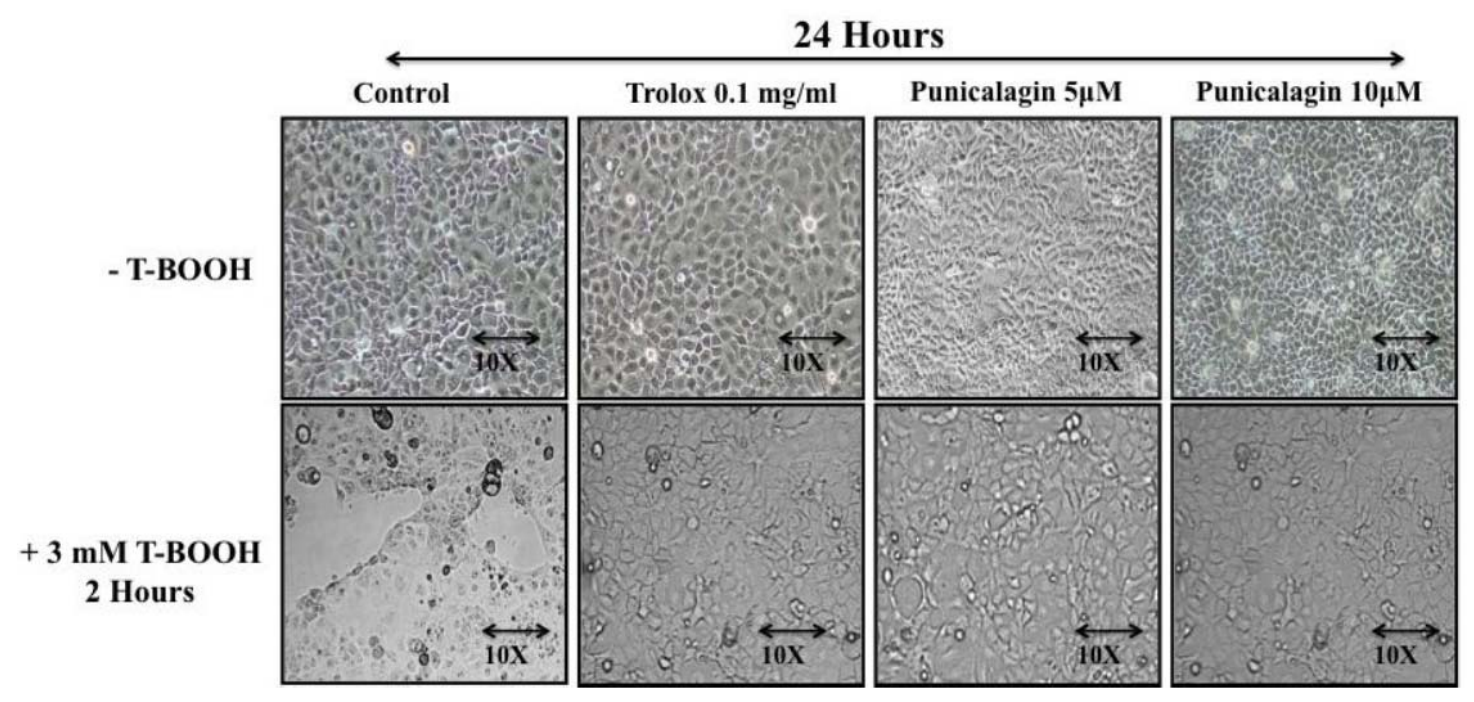

Figure 7: Effect of trolox and punicalagin on a Caco-2 cell line with/without $3 \mathrm{mM} \mathrm{t-BOOH}$ for 24 hours. Cells were treated with trolox and punicalagin for 24 hours. The pre-treated cells incubated with $3 \mathrm{mM} \mathrm{t}-\mathrm{BOOH}$ for 2 hours. Images were captured using light microscopy (magnification 10x).

Malondialdehyde (MDA) is one of the main products of lipid peroxidation [18]. It is produced in high quantities in various diseases and it is related to free radical damage [19]. Quercetin (a flavonol from a class of flavonoids) of 5 and $10 \mu \mathrm{M}$ incubated for 2 and 20 hours in HepG2 cells significantly inhibited the production of MDA under oxidative stress conditions induced by $200 \mu \mathrm{M}$ t-BOOH after 3 hours incubation period [20]. Another study by Peng and Kuo in 2003, discovered that $0.1 \mu \mathrm{M}$ quercetin, $10 \mu \mathrm{M}$ luteolin and 1 $\mu \mathrm{M}$ epigallocatechin gallate had the ability to inhibit lipid peroxidation in Caco-2 cells under $30 \mu \mathrm{M} \mathrm{H}_{2} \mathrm{O}_{2}+$ $30 \mu \mathrm{M} \mathrm{FeSO}_{4}$ inductive conditions [21]. Results from a study by Lima et al., (2007) on phenolic compounds extracted from Salvia officinalis (an aromatic plant) showed a significant inhibition in MDA concentration in HepG2 cells under oxidative stress. The water and methanolic extracts at 250 and $16 \mu \mathrm{g} / \mathrm{ml}$, respectively, incubated for 40 hours afforded protection to $80 \%$ of HepG2 cells and had the ability to prevent lipid peroxidation produced by $2 \mathrm{mM} \mathrm{t}-\mathrm{BOOH}$ for 5 hours [14]. The most abundant phenolic compounds present in the Salvia officinalis plant were rosmarinic acid and luteolin-7-glucoside [14]. All of the previous findings discussed above are similar to our result that punicalagin has the ability to prevent production of MDA in the Caco-2 cell line when under stress from 3 $\mathrm{mM}$ of $\mathrm{t}-\mathrm{BOOH}$. The ability of phenolic compounds to 
scavenge peroxides and prevent lipid peroxidation reaction of cell membrane could explain the observed reduction in MDA as lipid peroxidation marker [22].

Previous studies have shown that the powerful of antioxidant compounds occurs via ROS scavenging [23]. Therefore, The effect of punicalagin as a ROS scavenger was studied in the current research on Caco-2 cells. The ability of different flavonoids (quercetin, kaempferol and luteolin) to decrease the amount of ROS was measured by Yokomizo and Moriwaki (2006). In their study, each flavonoid (50 $\mu \mathrm{M})$ was incubated for 1 hour with the Caco-2 cell line. The pre-treated cell line was stressed by $50 \mu \mathrm{M} \mathrm{H}_{2} \mathrm{O}_{2}$ for 1 hour. The three flavonoids caused a significant decrease in ROS levels. Quercetin (54\%) was the most effective, followed by luteolin (34\%) and then kaempferol (26\%) [23]. ROS production was also significantly reduced in the HepG2 liver cell line when incubated with quercetin and rutin $(1-100 \mu \mathrm{M})$ for 24 hours when stressed with $200 \mu \mathrm{M} \mathrm{H} \mathrm{H}_{2}$ or 3 hours compared with cells without pre-treatment [24].

In agreement with previous results, the ability of examined concentration 5 and $10 \mu \mathrm{M}$ phenolic compound (punicalagin) to decrease cellular ROS levels in stressed Caco-2 with $3 \mathrm{mM} \mathrm{t}-\mathrm{BOOH}$ was observed. This finding may explain the importance of the presence of the phenolic hydroxyl group that scavenges radicals [23].

Glutathione (a non-enzymatic antioxidant) has an important protective role against ROS in the cell [18]. Increased intracellular oxidation leads to depletion of glutathione [17, 25]. Conversely, an increased level of glutathione protects the cell from the harmful effect of ROS. Therefore, the level of glutathione in Caco-2 cells pretreated with punicalagin under $\mathrm{t}-\mathrm{BOOH}$ oxidative stress conditions was measured. Our data showed that glutathione significantly increased to $0.3 \mathrm{nmol} / \mathrm{mg}$ in pretreated cells compared with untreated cells 0.18 $\mathrm{nmol} / \mathrm{mg}$ under oxidative stress conditions, which indicates significant depletion due to increased ROS levels. From this point of view, the protective effect of polyphenols as radical scavengers could help to maintain glutathione levels under oxidative stress conditions as demonstrated in other published research concerning the effect of polyphenols on human health $[14,24]$. Research by Lima et al., (2006) indicates that polyphenols provide protection against oxidative damage induced by t-BOOH. Luteolin $200 \mu \mathrm{M}, 45 \mu \mathrm{M}$ quercetin, $370 \mu \mathrm{M}$ caffeic acid and $180 \mu \mathrm{M}$ rosmarinic acid all had the ability to inhibit the GSH depletion in the HepG2 liver cell line [5]. Lima et al., (2007) reported the protective effect of polyphenols extracted from the salvia plant, using the same liver cell line. GSH depletion was significantly prevented by pre-treating cells with methanolic and water extract of salvia. In all of Lima's research, the oxidative stress induced in the liver cell line was caused by treatment with $2 \mathrm{mM} \mathrm{t}$ $\mathrm{BOOH}$ for 5 hours [14]. GSH has an important role in the protection of cells against ROS and free radicals. A severe reduction in GSH levels increases the susceptibility of cell damage by free radicals. Depletion of GSH levels has been suggested as one of the important mechanisms through with $\mathrm{t}-\mathrm{BOOH}$ induces cell toxicity [25]. Therefore, the potential effect of punicalagin against $\mathrm{t}-\mathrm{BOOH}$ as radical scavenging activity could maintain the GSH levels and contribute to their cytoprotective effects.

Trolox is partial hydrophobic in nature therefore its transfer through the cell is possibly hampered. Consequently, trolox might be kept partially within the cell membranes. Therefore, it will be near to the tight junction complexes where it can more easily defuse the direct oxidative effect of $\mathrm{t}-\mathrm{BOOH}$ on these protein structures and prevent their effect [26].

In conclusion, punicalagin at low concentrations had a protective effect against oxidative damage induced by $3 \mathrm{mM} \mathrm{t}-\mathrm{BOOH}$ in a Caco-2 cell line, and may therefore be a useful natural antioxidant. From our experiments, we observed that punicalagin strongly protected Caco-2 cells against cell death, by cellular ROS scavenging and preventing of lipid peroxidation. Moreover GSH depletion caused by $3 \mathrm{mM}$ t-BOOH was prevented by treating Caco-2 cells with punicalagin. These findings suggest that punicalagin may afford protection against excessive ROS production.

\section{REFERENCES}

[1] Wijeratne SSK, Cuppett SL, Schlegel V. Hydrogen peroxide induced oxidative stress damage and antioxidant enzyme response in caco-2 human colon cells. J Agric Food Chem 2005; 53: 8768-8774. http://dx.doi.org/10.1021/jf0512003

[2] Devasagayam TP, Boloor KK, Ramasarma T. Methods for estimating lipid peroxidation: an analysis of merits and demerits. Indian J Biochem Biophys 2003; 40: 300-8.

[3] Castell JV, Gomez-lechon MJ, Ponsoda X, Bort R. In vitro investigation of the molecular mechanisms of hepatotoxicity. Arch Toxicol Suppl 1997; 19: 313-21.

http://dx.doi.org/10.1007/978-3-642-60682-3 29

[4] Kedderis GL. Biochemical basis of hepatocellular injury. Toxicol Pathol 1996; 24: 77-83. http://dx.doi.org/10.1177/019262339602400111

[5] Lima CF, Fernandes-ferreira M, Pereira-wilson C. Phenolic compounds protect hepg2 cells from oxidative damage: relevance of glutathione levels. Life Sci 2006; 79: 2056-68. http://dx.doi.org/10.1016/j.lfs.2006.06.042 
[6] Steinmetz KA, Potter JD. Vegetables, fruit, and cancer prevention: a review. J Am Diet Assoc 1996; 96: 1027-39. http://dx.doi.org/10.1016/S0002-8223(96)00273-8

[7] Arts IC, Jacobs DR, Harnack IJ, Gross M, Folsom AR. Dietary catechins in relation to coronary heart disease death among postmenopausal women. Epidemiology 2001; 12: 668-75.

http://dx.doi.org/10.1097/00001648-200111000-00015

[8] Gil MI, Tomas-barberan FA, Hess-pierce B, Holcroft DM, Kader AA. Antioxidant activity of pomegranate juice and its relationship with phenolic composition and processing. $\mathrm{J}$ Agric Food Chem 2000; 48: 4581-9. http://dx.doi.org/10.1021/jf000404a

[9] Cotelle N, Bernier JL, Catteau JP, Pommery J, Wallet JC, Gaydou EM. Antioxidant properties of hydroxy-flavones. Free Radic Biol Med 1996; 20: 35-43.

http://dx.doi.org/10.1016/0891-5849(95)02014-4

[10] Van acker SA, Van den berg DJ, Tromp MN, et al. Structural aspects of antioxidant activity of flavonoids. Free Radic Biol Med 1996; 20: 331-42. http://dx.doi.org/10.1016/0891-5849(95)02047-0

[11] Cao G, Sofic E, Prior RL. Antioxidant and prooxidant behavior of flavonoids: structure-activity relationships. Free Radic Biol Med 1997; 22: 749-60.

http://dx.doi.org/10.1016/S0891-5849(96)00351-6

[12] Jouvet $\mathrm{P}$, Rustin P, Taylor DL, et al. Branched chain amino acids induce apoptosis in neural cells without mitochondrial membrane depolarization or cytochrome c release: implications for neurological impairment associated with maple syrup urine disease. Mol Biol Cell 2000; 11: 19191932. http://dx.doi.org/10.1091/mbc.11.5.1919

[13] Waterfield CJ, Westmoreland C, Asker DS, Murdock JC, George E, Timbrell JA. Ethionine toxicity in vitro: the correlation of data from rat hepatocyte suspensions and monolayers with in vivo observations. Archives of Toxicology 1998; 72: 588-596.

http://dx.doi.org/10.1007/s002040050547

[14] Lima CF, Valentao PC, Andrade PB, Seabra RM, Fernandesferreira $M$, Pereira-wilson $C$. Water and methanolic extracts of salvia officinalis protect hepg2 cells from t-bhp induced oxidative damage. Chem Biol Interact 2007; 167: 107-15. http://dx.doi.org/10.1016/i.cbi.2007.01.020

[15] Liu J, Yeo HC, Doniger SJ, Ames B. N. Assay of aldehydes from lipid peroxidation: gas chromatography-mass spectrometry compared to thiobarbituric acid. Anal Biochem 1997; 245: 161-6. http://dx.doi.org/10.1006/abio.1996.9990

[16] Ohkawa H, Ohishi N, Yagi K. Assay for lipid peroxides in animal tissues by thiobarbituric acid reaction. Anal Biochem 1979; 95: 351-8.

http://dx.doi.org/10.1016/0003-2697(79)90738-3
[17] Osseni RA, Debbasch C, Christen MO, Rat P, Warnet JM. Tacrine-induced reactive oxygen species in a human liver cell line: the role of anethole dithiolethione as a scavenger. Toxicol In Vitro 1999; 13: 683-8.

http://dx.doi.org/10.1016/S0887-2333(99)00050-8

[18] Suttnar J, Cermak J, Dyr JE. Solid-phase extraction in malondialdehyde analysis. Anal Biochem 1997; 249: 20-3. http://dx.doi.org/10.1006/abio.1997.2157

[19] Suttnar J, Masova I, Dyr JE. Influence of citrate and edta anticoagulants on plasma malondialdehyde concentrations estimated by high-performance liquid chromatography. J Chromatogr B Biomed Sci Appl 2001; 751: 193-7. http://dx.doi.org/10.1016/S0378-4347(00)00453-9

[20] Alia M, Ramos S, Mateos R, Granado-serrano AB, Bravo I, Goya I. Quercetin protects human hepatoma hepg2 against oxidative stress induced by tert-butyl hydroperoxide. Toxicol Appl Pharmacol 2006b; 212: 110-8. http://dx.doi.org/10.1016/j.taap.2005.07.014

[21] Peng IW, Kuo SM. Flavonoid structure affects the inhibition of lipid peroxidation in caco-2 intestinal cells at physiological concentrations. J Nutr 2003; 133: 2184-7.

[22] Brown JE, Khodr H, Hider RC, Rice-evans CA. Structural dependence of flavonoid interactions with cu2+ ions: implications for their antioxidant properties. Biochem J 1998; 330: 1173-8. http://dx.doi.org/10.1042/bj3301173

[23] Yokomizo A, Moriwaki M. Effects of uptake of flavonoids on oxidative stress induced by hydrogen peroxide in human intestinal caco-2 cells. Biosci Biotechnol Biochem 2006; 70: 1317-24. http://dx.doi.org/10.1271/bbb.50604

[24] Alia M, Mateos R, Ramos S, Lecumberri E, Bravo I, Goya I. Influence of quercetin and rutin on growth and antioxidant defense system of a human hepatoma cell line (hepg2). Eur J Nutr 2006a; 45: 19-28. http://dx.doi.org/10.1007/s00394-005-0558-7

[25] Martin C, Martinez R, Navarro R, Ruiz-sanz JI, Lacort M, Ruiz-larrea MB. Tert-butyl hydroperoxide-induced lipid signaling in hepatocytes: involvement of glutathione and free radicals. Biochem Pharmacol 2001; 62: 705-12. http://dx.doi.org/10.1016/S0006-2952(01)00704-3

[26] Vergauwen H, Tambuyzer B, Jennes K, Degroote J, Wang W, De smet S, Van ginneken C. Trolox and ascorbic acid reduce direct and indirect oxidative stress in the ipec-j2 cells, an in vitro model for the porcine gastrointestinal tract. Plos one $2015 ; 10(3)$. http://dx.doi.org/10.1371/journal.pone.0120485

\section{DOI: http://dx.doi.org/10.6000/1927-5951.2015.05.04.5}

(C) 2015 Omar et al.; Licensee Lifescience Global.

This is an open access article licensed under the terms of the Creative Commons Attribution Non-Commercial License (http://creativecommons.org/licenses/by-nc/3.0/) which permits unrestricted, non-commercial use, distribution and reproduction in any medium, provided the work is properly cited. 